\title{
TACSTD2 Gene
}

National Cancer Institute

\section{Source}

National Cancer Institute. TACSTD2 Gene. NCI Thesaurus. Code C17774.

This gene plays a regulatory role in intracellular calcium signal transduction. 